\title{
A prospective study of hypothyroidism during pregnant attending tertiary care hospital in south India
}

\author{
G. Sravani, M. Smitha* \\ Department of Obstetrics and Gynaecology, Konaseema Institute of Medical Science Amalapuram Andhra Pradesh,
} India

Received: 05 December 2020

Accepted: 17 December 2020

*Correspondence:

Dr. M. Smitha,

E-mail: drmsmitha@gmail.com

Copyright: (C) the author(s), publisher and licensee Medip Academy. This is an open-access article distributed under the terms of the Creative Commons Attribution Non-Commercial License, which permits unrestricted non-commercial use, distribution, and reproduction in any medium, provided the original work is properly cited.

\begin{abstract}
Background: Disorder of thyroid function is common during pregnancy and hypothyroidism is more common then hyperthyroidism affecting 3-5\% of all pregnant women. Maternal hypothyroidism is associated with both maternal adverse effects like preeclampsia, ecclampsia, pregnancy induced hypertension and gestational diabetes mellitus and foetus complication like low birth weight, pre term birth, neurological deformities and abnormal presentation.

Methods: In present study 120 patients with overt and subclinical hypothyroidism were included in this study. Detailed histories of patients were taken and clinical examination was done and data was collected in a predesigned Performa. We used standard diagnostic criteria for diagnosis of overt and subclinical hypothyroidism.

Results: Pregnancy induced hypertension was found in $10 \%$ patient, Chronic hypertension was present in $1.6 \%$ patients, abortion in second trimester $1.6 \%$ patients, incomplete abortion in $4.18 \%$ patients. Missed abortion was present in $2.5 \%$ patients.

Conclusions: Hypothyroidism during pregnancy is more common in primi. Most common age group was third decade and was commonly detected before 10 weeks of gestation. Pregnancy induced hypertension, oligohydramnios and preterm delivery was more common than abortion in second trimester and missed abortion.
\end{abstract}

Keywords: Complications, Hypothyroidism, Pregnancy

\section{INTRODUCTION}

Normal functioning of thyroid gland is essential during pregnancy for both mother and growing foetus. For normal growth and development of foetus adequate transplacental transfer of thyroid hormone is essential as synthesis and secretion of thyroid hormone in foetus start only after 20 week of gestation. ${ }^{1,2}$ Disorder of thyroid function is common during pregnancy and hypothyroidism is more common then hyperthyroidism affecting $3-5 \%$ of all pregnant women. ${ }^{3,4}$ There are various factor which is responsible for abnormal thyroid function like during pregnancy there occurs increase in thyroid hormone binding globulin (TBG) level which increase the need for T3 and T4 production throughout pregnancy. There is increased degradation of thyroid hormone by placental, chorion, and amnion type 3 inner ring deiodinase. Serum thyroid antibody positivity is also common during pregnancy. ${ }^{5-7}$

There is a well established association between maternal hypothyroidism and adverse outcome of pregnancy. ${ }^{8,9}$ Maternal hypothyroidism is associated with both maternal adverse effects like preeclampsia, ecclampsia, pregnancy induced hypertension and gestational diabetes mellitus and foetus complication like low birth weight, pre term birth, neurological deformities and abnormal presentation. ${ }^{10,11}$

Dhanwal DK, Bajaj S, Rajput R, et al in their prevalence study from 11 cities in 9 states of India has concluded that there is a high prevalence of hypothyroidism $(13.13 \%)$, in pregnant women during the first trimester from India and universal screening of hypothyroidism 
may be desirable in our country. ${ }^{12}$ Kalra B, Choudhary M, Thakral M, Kalra $S$ et al has concluded that Hypothyroidism is common in term pregnancies. If treated adequately, healthy fetomaternal outcomes can be achieved. ${ }^{13}$

Present study has been undertaken to know the prevalence of hypothyroidism in our region and its presentation and also to follow the patients till delivery after adequate treatment.

\section{METHODS}

\section{Place of study}

Present study has been conducted in the department of obstetrics and gynaecology Konaseema institute of medical science Amalapuram Andhra Pradesh India.

\section{Duration of study}

It has been conducted from January 2018 to August 2020.

\section{Type of study}

This is a prospective observational study.

\section{Selection of patients}

All pregnant women attending antenatal outpatient department for their first antenatal check-up were approached and in addition to routine lab investigation thyroid function test was advised. Out of them patients were selected based o following inclusion and exclusion criteria.

\section{Inclusion criteria}

1) All singleton pregnancy in first and second trimester

2) Overt and subclinical patients with or without treatment

\section{Exclusion criteria}

1) Multiple pregnancies

2) Gestational diabetes mellitus

\section{Sample size}

Based on above criteria 120 patients were enrolled for this study.

\section{Method}

In present study 120 patients with overt and subclinical hypothyroidism were included in this study. Detailed histories of patients were taken and clinical examination was done and data was collected in a predesigned Performa. We used standard diagnostic criteria for diagnosis of overt and subclinical hypothyroidism 15, 16. For estimation of thyroid hormone we used radioimmunoassay and Solid Phase Two-Site ImmunoRadoMetric Assay technique. All women enrolled for this study were followed for till delivery to see that they develop any complication and know the outcome of pregnancy. All patients were treated as per standard treatment protocol.

\section{Statistical analysis}

Data were recorded in excel sheet and statistical Analysis was done with software SPSS-14 version. Data were calculated as percentage and proportions.

\section{RESULTS}

In present study during study period 980 patients attending obstetrics outpatient department were evaluated for hypothyroidism out of them 120 patients with hypothyroidism were enrolled for this study.

Table 1: Clinical and demographic profile of the patients with hypothyroidism.

\begin{tabular}{|c|c|c|c|}
\hline Variables & & Frequency & Percentage \\
\hline \multirow{4}{*}{$\begin{array}{l}\text { Age in } \\
\text { years }\end{array}$} & $\begin{array}{l}\text { Less } \\
\text { than } 20\end{array}$ & 16 & 13.3 \\
\hline & 21 to 30 & 25 & 20.83 \\
\hline & 31 to 40 & 53 & 44.16 \\
\hline & $\begin{array}{l}\text { More } \\
\text { than } 41\end{array}$ & 26 & 21.66 \\
\hline \multirow{2}{*}{$\begin{array}{l}\text { Gestational } \\
\text { age }\end{array}$} & $\begin{array}{l}\text { Less } \\
\text { than } 10 \\
\text { wks }\end{array}$ & 96 & 80 \\
\hline & $\begin{array}{l}\text { More } \\
\text { than } 10 \\
\text { wks }\end{array}$ & 24 & 20 \\
\hline \multirow{2}{*}{ Gravidity } & primi & 78 & 65 \\
\hline & multi & 42 & 35 \\
\hline \multirow{3}{*}{$\begin{array}{l}\text { Serum } \\
\text { TSH in } \\
\mathrm{mIU} / \mathrm{ml}\end{array}$} & 3 to 5 & 12 & 10 \\
\hline & 5 to 10 & 76 & 63.3 \\
\hline & $\begin{array}{l}\text { More } \\
\text { than } 10\end{array}$ & 32 & 26.3 \\
\hline \multirow{2}{*}{$\begin{array}{l}\text { Treatment } \\
\text { status at } \\
\text { admission }\end{array}$} & Treated & 72 & 60 \\
\hline & $\begin{array}{l}\text { Not } \\
\text { treated }\end{array}$ & 48 & 40 \\
\hline
\end{tabular}

As per table regarding clinical and demographic profile of patients 13.335 patients were below 20 year of age, $20.83 \%$ patients were between 21 to 30 years of age, $44.16 \%$ patients were between 31 to 40 years of age and $21.66 \%$ of patients were above 41 year of age.in this study $80 \%$ patients were below 10 weeks of gestation and $20 \%$ were above 10 weeks of gestation. Regarding gravidity of patients $65 \%$ patients were primi and $35 \%$ patients were multi. Serum TSH was between 3 to 5 
$\mathrm{mIU} / \mathrm{ml}$ in $10 \%$ patients, 5 to $10 \mathrm{mIU} / \mathrm{ml}$ in $63.3 \%$ and more than $10 \mathrm{mIU} / \mathrm{ml}$ in $26.3 \%$ patients. At the time of admission $60 \%$ patient were taking treatment and $40 \%$ patient were not treated.

Table 2: Complication in patients with hypothyroidism during pregnancy.

\begin{tabular}{|lll|}
\hline Variables & Frequency & Percentage \\
\hline $\begin{array}{l}\text { Frequency of absent } \\
\text { Complication }\end{array}$ & 78 & 65 \\
\cline { 2 - 3 } $\begin{array}{l}\text { Pregnancy induced } \\
\text { hypertension }\end{array}$ & 42 & 35 \\
\hline $\begin{array}{l}\text { Chronic hypertension } \\
\text { Abortion in second }\end{array}$ & 2 & 10 \\
trimester & 2 & 1.6 \\
\hline Incomplete abortion & 5 & 1.6 \\
\hline Missed Abortion & 3 & 4.18 \\
\hline Preterm delivery & 16 & 2.5 \\
\hline Oligohydramnios & 12 & 13.33 \\
\hline
\end{tabular}

As per table 2, regarding complication in patients with hypothyroidism during pregnancy $65 \%$ of patients have developed complication. Pregnancy induced hypertension was found in $10 \%$ patient, Chronic hypertension was present in $1.6 \%$ patients, abortion in second trimester $1.6 \%$ patients, incomplete abortion in $4.18 \%$ patients. Missed abortion was present in $2.5 \%$ patients. Preterm delivery and oligohydramnios was present in $13.33 \%$ and $10 \%$ patient respectively.

Table 3: Mode of delivery in patients with hypothyroidism.

\begin{tabular}{|lll|}
\hline Variables & Frequency & Percentage \\
\hline $\begin{array}{l}\text { Normal vaginal } \\
\text { delivery }\end{array}$ & 58 & 48.33 \\
\hline Preterm & 16 & 13.33 \\
\hline Forceps & 2 & 1.66 \\
\hline Elective CS & 34 & 28.33 \\
\hline Emergency CS & 20 & 16.66 \\
\hline
\end{tabular}

Regarding mode of delivery of patients with hypothyroidism, $48.33 \%$ have normal vaginal delivery, $13.33 \%$ have normal vaginal delivery, and $1.66 \%$ has forceps assisted delivery. Elective CS was mode of delivery in $28.33 \%$ and emergency CS was mode of delivery in $16.66 \%$.

\section{DISCUSSION}

We have evaluated 980 women with pregnancy for hypothyroidism during our study period of two years and eight months and observed that $12.22 \%$ women have hypothyroidism. Dhanwal DK, Bajaj S, Rajput R, et al has reported from his multicentric study that prevalace of hypothyroidism during pregnancy in India to be $13.13 \%$ and in Andhra Pradesh to $8.94 \%$ which is little less than our study but close to whole India prevalence. ${ }^{12}$ Korde
VR, Barse SP, Barla JS et al has reported that in his study the prevalence was $14 \%$ which is similar to our study. ${ }^{16}$

We have observed that hypothyroidism during pregnancy is more common in primi. Most common age was from 31 to 40 years and was commonly detected before 10 weeks of gestation which is supported by the work of Vimal Nambiar, Varsha S. Jagtap, Vijaya Sarathi et al. ${ }^{17}$ In present study most of the patient TSH was between 5 to $10 \mathrm{mIU} / \mathrm{ml}$ and at the time of admission $60 \%$ patient were taking treatment and $40 \%$ patient were not treated. Which is supported by the work of Vimal Nambiar et al and Teng X, Shan Z, Chen Y, Lai Y, Yu J, Shan L, et al. ${ }^{17,18}$ In our study pregnancy induced hypertension, oligohydramnios and preterm delivery was more common than abortion in second trimester and missed abortion. This finding corroborates with the study of Tudosa R, Vartej P, Horhoianu I, Ghica C, Mateescu S, Dumitrache Iet al and Casey BM, Dashe JS, Wells CE, et al. ${ }^{19,20}$

Regarding mode of delivery in our study normal vaginal delivery was most common (48.33\%). Tudosa R, Vartej P, Horhoianu I, Ghica C, Mateescu S, Dumitrache I et al has reported that spontaneous delivery was $53.33 \%$ which is little higher the our study. Elective CS was mode of delivery in $28.33 \%$ and emergency CS was mode of delivery in $16.66 \%$ which is less than the study of Tudosa R, Vartej P et al. ${ }^{19}$ Casey BM, Dashe JS, Wells CE, et al has concluded that Preterm birth, defined as delivery at or before 34 weeks of gestation, was almost 2-fold higher in women with subclinical hypothyroidism which support our study. ${ }^{20}$

\section{CONCLUSION}

From our study we can conclude that the prevalence of hypothyroidism in our region was $12.22 \%$. Hypothyroidism during pregnancy is more common in primi. Most common age group was third decade and was commonly detected before 10 weeks of gestation. Pregnancy induced hypertension, oligohydramnios and preterm delivery was more common than abortion in second trimester and missed abortion. Normal vaginal delivery was common then elective or emergency CS.

Funding: No funding sources

Conflict of interest: None declared

Ethical approval: The study was approved by the Institutional Ethics Committee

\section{REFERENCES}

1. Leung AM. Thyroid function in pregnancy, J Trace Elem Med Biol. 2012;26(2-3):137-40.

2. Brown RS. Mini review: developmental regulation of thyrotropin receptor gene expression in the fetal and newborn thyroid. Endocrinol. 2004;145(9):4058-61.

3. Jansen TA, Korevaar TIM, Mulder TA, White T, Muetzel RL, Peeters RP, et al. Maternal thyroid function during pregnancy and child brain 
morphology: a time window-specific analysis of a prospective cohort, The Lancet Diabetes \& Endocrinol. 2019;7(8):19.

4. Teng W, Shan Z, Sisodia KP, Cooper DS. Hypothyroidism in pregnancy, The Lancet Diabetes \& Endocrinol. 2013;1(3):228-37.

5. Castillo Lara M, Vilar Sánchez Á, Cañavate Solano C, Soto Pazos E, Iglesias Álvarez M, González Macías C, Ayala Ortega C, Moreno Corral LJ, Fernández Alba JJ.Hypothyroidism screening during first trimester of pregnancy". BMC Pregnancy Childbirth. 2017 Dec 22;17(1):438. doi: 10.1186/s12884-017-1624-x.

6. Mandel SJ, Spencer CA, Hollowell JG. Are detection and treatment of thyroid insufficiency in pregnancy feasible? Thyroid. 2005;15(1):44-53.

7. Roti E, Fang SL, Emerson $\mathrm{CH}$, Braverman LE. Placental inner ring iodothyronine deiodination: a mechanism for decreased passage of T4 and T3 from mother to fetus. Trans Assoc Am Physicians. 1981;94:183-9.

8. Allan WC, Haddow JE, Palomaki GE, Williams JR, Mitchell ML, Hermos RJ, et al. Maternal thyroid deficiency and pregnancy complications: implications for population screening. J Med Screen. 2000;7(3):127-30.

9. Abalovich M, Gutierrez S, Alcaraz G, Maccallini G, Garcia A, Levalle O. Overt and subclinical hypothyroidism complicating pregnancy. Thyroid. 2002;12(1):63-8.

10. Leung AS, Millar LK, Koonings PP, Montoro M, Mestman JH. Perinatal outcome in hypothyroid pregnancies. Obstet Gynecol. 1993;81(3):349-53.

11. Idris I, Srinivasan R, Simm A, Page RC. Maternal hypothyroidism in early and late gestation: effects on neonatal and obstetric outcome..Clin Endocrinol. (Oxf). 2005;63(5):560-5.

12. Dhanwal DK, Bajaj S, Rajput R. Prevalence of hypothyroidism in pregnancy: An epidemiological study from 11 cities in 9 states of India. Indian J Endocrinol Metab. 2016;20(3):387-90.

13. Kalra B, Choudhary M, Thakral M, Kalra S. Prevalence of Hypothyroidism in Term Pregnancies in North India. Indian $\mathrm{J}$ Endocrinol Metab. 2018;22(1):13-5.

14. Thyroid Disease and Pregnancy Available at: http://www.thyroid.org/ thyroid-disease-pregnancy/ on 10 September 2020.

15. Maraka S. Thyroid hormone treatment among pregnant women with subclinical hypothyroidism: US national assessment. BMJ. 2017;356:i6865.

16. Korde VR, Barse SP, Barla JS. Prevalence of thyroid dysfunctions in pregnant women: a prospective study in a tertiary care hospital in Maharashtra, India. Int J Reprod Contracept Obstet Gynecol. 2018;7:3211-5.

17. Nambiar V, Jagtap VS, Sarathi V, Lila AR, Kamalanathan S, Bandgar TR. "Prevalence and Impact of Thyroid Disorders on Maternal Outcome in Asian-Indian Pregnant Women", J Thyroid Res. 2011:6.

18. Teng X, Shan Z, Chen Y, Lai Y, Yu J, Shan L, et al. More than adequate iodine intake may increase subclinical hypothyroidism and autoimmune thyroiditis: a cross-sectional study based on two Chinese communities with different iodine intake levels. Eur J Endocrinol. 2011;164:943-50.

19. Tudosa R, Vartej P, Horhoianu I, Ghica C, Mateescu S, Dumitrache I. Maternal and fetal complications of the hypothyroidism-related pregnancy. Maedica (Bucur). 2010;5(2):116-23.

20. Casey BM, Dashe JS, Wells CE. Subclinical hypothyroidism and pregnancy outcomes. Obstet Gynecol. 2005;105:239-45.

Cite this article as: Sravani G, Smitha M. A prospective study of hypothyroidism during pregnant attending tertiary care hospital in south India. Int $\mathbf{J}$ Reprod Contracept Obstet Gynecol 2021;10:326-9. 